\title{
Natural history of ventricular septal defect with right-sided aortic $\operatorname{arch}^{1}$
}

\author{
P. J. Varghese, J. R. Allen, G. C. Rosenquist, and R. D. Rowe \\ From the Department of Pediatrics, The fohns Hopkins University School of Medicine, \\ and Cardiac Clinic, Children's Medical and Surgical Center, The fohns Hopkins Hospital, \\ Baltimore, Maryland, U.S.A.
}

The natural history of 14 patients with ventricular septal defect and right-sided aortic arch is reviewed. Patients are divided into two groups. Group $A$ consisted of Io patients, all of whom developed progressive infundibular stenosis; group $B$ consisted of 4 patients, none of whom developed infundibular stenosis. The clinical features, $\mathrm{x}$-rays, electrocardiograms, haemodynamic data, and angiocardiograms in these two groups are compared.

The right ventricular cine-angiocardiogram seems to be helpful in differentiating the course of the two groups. The patients who developed progressive infundibular stenosis showed an abnormal right ventricular cine-angiocardiogram even in the absence of obstruction. Various aetiological factors for the development of infundibular stenosis are discussed.

The importance of medical management in group $A$ patients is emphasized, even though all of them presented in infancy in congestive heart failure. The role of propranolol in preventing cyanotic spells in group $A$ patients is also discussed.

Among many recent contributions to the natural history of ventricular septal defect in infants and children (Arcilla et al., 1963; Bloomfield, I964; Hoffman and Rudolph, 1965; Kidd et al., 1965; Ritter et al., 1965), no specific attention has been paid to ventricular septal defect with right-sided aortic arch as a separate entity. It has been a clinical impression that the course of this group of patients is different from patients with ordinary ventricular septal defect, and an examination of the natural history of patients with ventricular septal defect and right aortic arch was, therefore, undertaken. The serial clinical examination, electrocardiogram, $x$-ray, and cardiac catheterization of 14 subjects form the basis of the report.

\section{Subjects and methods}

Patients were selected from the registry of the Cardiac Clinic at the Children's Medical and Surgical Center of the Johns Hopkins Hospital on the basis of ( $\mathrm{I}$ ) radiological evidence of rightsided aortic arch and (2) cardiac catheterization evidence of ventricular septal defect with left-toright shunt as the only intracardiac lesion. Patients with one cardiac catheterization after infancy, Received 26 January 1970.

1 Supported by United States Public Health Service grants. which had shown left-to-right shunt at the ventricular level and significant infundibular stenosis, were included in the study only if they satisfied one of the following criteria: (I) history of congestive heart failure in infancy, (2) cardiomegaly on the chest $x$-ray as shown by a cardiothoracic ratio of at least 0.59 , with the right dome of the diaphragm at the ninth rib and increased pulmonary vascularity.

Fourteen patients satisfied the above criteria and were divided into two groups. Group A (Io cases): all except one (Case 10) presented in infancy in congestive heart failure. Case Io at the age of $6 \frac{1}{2}$ years had cardiomegaly and increased vascularity on the chest $x$-ray. All ro patients in group $A$ developed progressive infundibular stenosis during subsequent follow-up.

Group B (4 cases): 3 patients had congestive heart failure in infancy. The other had a small ventricular septal defect. None of these 4 patients developed infundibular stenosis during subsequent observation.

The clinical data for group $A$ are given in Table $I$ and for group B in Table 2, while haemodynamic data are presented for group $A$ in Table 3 and for group B in Table 4.

\section{Results}

Clinical presentation Congestive heart failure was the presenting feature in 9 cases in group $A$, and all ultimately responded to medical treatment, though in 2 the failure 
TABLE I Clinical data of patients who developed progressive infundibular stenosis (group $A$ )

\begin{tabular}{|c|c|c|c|c|c|c|c|c|c|c|c|c|}
\hline $\begin{array}{l}\text { Case } \\
\text { No. }\end{array}$ & $A g e$ & Sex & $\begin{array}{l}\text { Congestive } \\
\text { heart } \\
\text { failure }\end{array}$ & Cyanosis & $\begin{array}{l}\text { Heart } \\
\text { sounds }\end{array}$ & Murmurs & $\begin{array}{l}\text { Electroc } \\
\text { Axis }\end{array}$ & $\begin{array}{l}\text { cardiogr } \\
\text { Ventri } \\
\text { domin }\end{array}$ & $\begin{array}{l}\text { ram } \\
\text { iculo } \\
\text { rance }\end{array}$ & & $\begin{array}{l}\mathrm{X}-\text { ray } \\
C T R^{\star}\end{array}$ & $\begin{array}{l}\text { chest } \\
\text { Vascularity }\end{array}$ \\
\hline $\mathbf{I}$ & \multirow{2}{*}{$\begin{array}{l}7 \mathrm{mth} . \\
3 \mathrm{yr} .6 \mathrm{mth} . \\
15 \mathrm{mth} .\end{array}$} & \multirow{3}{*}{$\begin{array}{l}\mathbf{F} \\
\mathbf{F}\end{array}$} & \multirow{2}{*}{$\begin{array}{l}\text { Yes } \\
\text { No } \\
\text { Yes }\end{array}$} & \multirow{2}{*}{$\begin{array}{l}\text { No } \\
\text { No } \\
\text { No }\end{array}$} & \multirow{2}{*}{$\begin{array}{l}\mathbf{P}_{2} \uparrow \\
\mathbf{P}_{2} \downarrow \\
\mathbf{P}_{2} \uparrow\end{array}$} & \multirow{3}{*}{$\begin{array}{l}\text { Pansystolic (IV/VI); } \\
\text { mid-diastolic } \\
\text { (II/VI) } \\
\text { " \#, } \\
\text { Pansystolic (V/VI); } \\
\text { mid-diastolic } \\
\text { (II/VI) } \\
\text { Systolic ejection } \\
\text { (IV/VI); mid- } \\
\text { diastolic (II/VI) }\end{array}$} & \multirow{2}{*}{$\begin{array}{l}+60 \\
+90 \\
+90\end{array}$} & \multicolumn{3}{|c|}{$\begin{array}{l}\text { Combined } \\
\text { ventric. } \\
\text { hypertrophy }\end{array}$} & 57 & +++ \\
\hline \multirow[t]{2}{*}{2} & & & & & & & & " & & " & $\begin{array}{l}60 \\
60\end{array}$ & $\begin{array}{l}++ \\
+++\end{array}$ \\
\hline & $4 \mathrm{yr}$. & & No & No & $\mathrm{P}_{2} \mathrm{~N} \dagger$ & & +90 & 川 & $"$ & 》 & 60 & ++ \\
\hline \multirow[t]{2}{*}{3} & $2 \frac{1}{2} \mathrm{mth}$. & $\mathbf{F}$ & Yes & No & $\mathbf{P}_{2} \mathbf{N}$ & $\begin{array}{l}\text { Pansystolic (IV/VI); } \\
\text { mid-diastolic } \\
\text { (II/VI) }\end{array}$ & +50 & " & 川 & " & 65 & ++ \\
\hline & $3 \mathrm{yr}$. & & No & No & $\mathbf{P}_{2} \downarrow$ & $\begin{array}{l}\text { Systolic ejection } \\
\text { (IV/VI); no } \\
\text { mid-diastolic }\end{array}$ & +75 & 川 & 川 & 川 & 59 & + \\
\hline \multirow[t]{2}{*}{4} & 2 wk. & F & Yes & No & $\mathrm{P}_{2} \mathrm{~N}$ & $\begin{array}{l}\text { Systolic ejection } \\
\text { (II/V) }\end{array}$ & +90 & 川 & 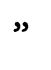 & 川 & 55 & + \\
\hline & $3 \mathrm{yr}$. & & No & $\begin{array}{l}\text { Cyanotic } \\
\text { spells }\end{array}$ & $\mathbf{P}_{2} \downarrow$ (absent) & $\begin{array}{l}\text { Systolic ejection } \\
\text { (IV/VI) }\end{array}$ & +100 & 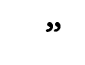 & 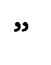 & 》 & 55 & + \\
\hline \multirow[t]{2}{*}{5} & $\mathrm{r} 6 \mathrm{mth}$ & $\mathbf{M}$ & $\begin{array}{l}\text { Yes } \\
\text { (at } 3 \text { wk.) }\end{array}$ & No & $\mathrm{P}_{2} \mathrm{~N}$ & Pansystolic (IV/VI) & -90 & $\begin{array}{l}\text { Rt. ve } \\
\text { hyp }\end{array}$ & pert & $\begin{array}{l}\text { ric. } \\
\text { trophy }\end{array}$ & 60 & ++ \\
\hline & $7 \mathrm{yr} .6 \mathrm{mth}$. & & No & No & $\underset{\text { (absent) }}{\mathbf{P}_{2} \downarrow}$ & $\begin{array}{l}\text { Systolic ejection } \\
\text { (IV/VI) }\end{array}$ & -100 & פ & M & 川 & 45 & $\mathbf{N}$ \\
\hline \multirow[t]{2}{*}{6} & 2 mth. & $\mathbf{M}$ & Yes & No & $\mathbf{P}_{2} \uparrow$ & $\begin{array}{l}\text { Pansystolic (IV/VI); } \\
\text { mid-diastolic } \\
\text { (II/VI) }\end{array}$ & +100 & $\begin{array}{l}\text { Comb } \\
\text { ven } \\
\text { hyp }\end{array}$ & $\begin{array}{l}\text { bine } \\
\text { ntric } \\
\text { pert }\end{array}$ & $\begin{array}{l}\text { ed } \\
\text { c. } \\
\text { trophy }\end{array}$ & 70 & ++ \\
\hline & $5 \mathrm{yr}$. & & No & No & $\mathbf{P}_{2} \mathbf{N}$ & $\begin{array}{l}\text { Systolic ejection } \\
\text { (IV/VI) }\end{array}$ & +100 & $"$ & $"$ & 川 & 56 & + \\
\hline 7 & $\begin{array}{l}\text { I } \frac{1}{2} \mathrm{mth} . \\
5 \mathrm{yr} .\end{array}$ & $\mathrm{F}$ & $\begin{array}{l}\text { Yes } \\
\text { No }\end{array}$ & $\begin{array}{l}\text { No } \\
\text { No }\end{array}$ & $\begin{array}{l}\mathbf{P}_{2} \uparrow \\
\mathbf{P}_{2} \downarrow\end{array}$ & $\begin{array}{l}\text { Pansystolic (IV/VI) } \\
\text { Systolic ejection } \\
\text { (IV/VI) }\end{array}$ & $\begin{array}{l}+70 \\
+90\end{array}$ & " & " & " & $\begin{array}{l}70 \\
54\end{array}$ & $\begin{array}{l}++ \\
+\end{array}$ \\
\hline 8 & $5 \mathrm{mth}$. & $\mathbf{M}$ & Yes & No & $\mathbf{P}_{\mathbf{2}} \uparrow$ & Pansystolic (IV/VI) & +50 & $\begin{array}{l}\text { Lt. ve } \\
\text { hyp }\end{array}$ & $\begin{array}{l}\text { entr } \\
\text { pert }\end{array}$ & $\begin{array}{l}\text { ric. } \\
\text { trophy }\end{array}$ & 55 & $+t$ \\
\hline 9 & $\left\{\begin{array}{l}4 \text { yr. } 6 \text { mth. } \\
13 \frac{1}{2} \text { mth. }\end{array}\right.$ & F & $\begin{array}{l}\text { No } \\
\text { Yes }\end{array}$ & $\begin{array}{l}\text { No } \\
\text { No }\end{array}$ & $\begin{array}{l}\mathbf{P}_{2} \downarrow \\
\mathbf{P}_{\mathbf{2}} \uparrow\end{array}$ & $\begin{array}{l}\text { Pansystolic (IV/VI) } \\
\text { Pansystolic (IV/VI); } \\
\text { mid-diastolic } \\
(\text { II/VI) }\end{array}$ & +50 & $\begin{array}{l}\text { Comb } \\
\text { ven } \\
\text { hyp }\end{array}$ & $\begin{array}{l}\text { bine } \\
\text { atric } \\
\text { perts }\end{array}$ & $\begin{array}{l}\text { ed } \\
\text { c. } \\
\text { trophy }\end{array}$ & $\begin{array}{l}52 \\
67\end{array}$ & $\begin{array}{l}\mathrm{N} \\
+++\end{array}$ \\
\hline 10 & $\left\{\begin{array}{l}3 \mathrm{yr} . \\
6 \mathrm{yr} .6 \mathrm{mth} . \\
8 \mathrm{yr} .9 \mathrm{mth} .\end{array}\right.$ & $\mathbf{M}$ & $\begin{array}{l}\text { No } \\
\text { No } \\
\text { No }\end{array}$ & $\begin{array}{l}\text { No } \\
\text { No } \\
\text { No }\end{array}$ & $\begin{array}{l}\mathbf{P}_{2} \mathbf{N} \\
\mathbf{P}_{2} \mathbf{N} \\
\mathbf{P}_{2} \mathbf{N}\end{array}$ & $\begin{array}{l}\text { No change } \\
\text { Pansystolic (V/VI) } \\
\text { Systolic ejection } \\
\text { (IV/VI) }\end{array}$ & $\begin{array}{r}+40 \\
+130 \\
+130\end{array}$ & $\begin{array}{l}\text { " } \\
"\end{array}$ & " & " & $\begin{array}{l}64 \\
59 \\
53\end{array}$ & $\begin{array}{l}++ \\
++ \\
N\end{array}$ \\
\hline
\end{tabular}

* CTR-cardiothoracic ratio.

t N-normal.

persisted for several weeks. One other patient in group A (Case Io) was referred at the age of $6 \frac{1}{2}$ years. A detailed previous history was not available because the patient had been separated from his parents and was living in another city with foster parents. His chest film showed a cardiothoracic ratio of 0.59 and much increased vascularity.

Of the 4 cases in group B, 3 presented during infancy in congestive heart failure. In Case II congestive heart failure persisted despite vigorous anticongestive measures and required pulmonary artery banding at the age of $9 \frac{1}{2}$ months. Case 12 responded to medical treatment but cardiac catheterization at the age of 9 years showed a large left-to-right shunt with moderate pulmonary hypertension. The ventricular defect was shortly thereafter closed surgically. Even though Case I4 presented at the age of $I$ month in heart failure, subsequent examinations have shown that the ventricular septal defect is becoming smaller. Though Case 13 had no previous history of heart failure, cardiac catheterization at the age of II years showed a small ventricular septal defect with an aneurysm of the membranous septum.

All I4 cases were acyanotic at the initial visit and contintued to be acyanotic except for Case 4 in group A. This patient at the age of 2 years developed cyanotic spells, but spontaneous remission of the episodes occurred 
TABLE 2 Clinical data of patients who did not develop progressive infundibular stenosis (group $B$ )

\begin{tabular}{|c|c|c|c|c|c|c|c|c|c|c|}
\hline $\begin{array}{l}\text { Case } \\
\text { No. }\end{array}$ & Age & Sex & $\begin{array}{l}\text { Congestive } \\
\text { heart } \\
\text { failure }\end{array}$ & Cyanosis & $\begin{array}{l}\text { Heart } \\
\text { sounds }\end{array}$ & Murmurs & $\begin{array}{l}\text { Electroc } \\
\text { Axis }\end{array}$ & $\begin{array}{l}\text { cardiogram } \\
\text { Ventricular } \\
\text { dominance }\end{array}$ & $\begin{array}{l}\text { X-ray } \\
C T R^{\star}\end{array}$ & $\begin{array}{l}\text { chest } \\
\text { Vascularity }\end{array}$ \\
\hline \multirow[t]{2}{*}{ I I } & \multirow{2}{*}{$\begin{array}{l}3 \frac{1}{2} \mathrm{mth} . \\
9 \frac{1}{2} \mathrm{mth}\end{array}$} & \multirow[t]{2}{*}{$\mathbf{M}$} & Yes & No & & Pansystolic (III/VI) & Indet. & $\begin{array}{l}\text { Rt. ventric. } \\
\text { hypertrophy }\end{array}$ & 67 & +++ \\
\hline & & & Yes & No & $\mathbf{P}_{2} \uparrow$ & $\begin{array}{l}\text { Pansystolic (V/VI); } \\
\text { mid-diastolic } \\
(\mathrm{II} / \mathrm{VI})\end{array}$ & Indet. & $" \#$ & 65 & ++ \\
\hline 12 & $6 \mathrm{mth}$. & $\mathbf{M}$ & Yes & No & $\mathbf{P}_{2} \uparrow$ & $\begin{array}{l}\text { Pansystolic (IV/VI); } \\
\text { mid-diastolic } \\
\text { (II/VI) }\end{array}$ & +80 & $\begin{array}{l}\text { Combined } \\
\text { ventric. } \\
\text { hypertrophy }\end{array}$ & 65 & ++ \\
\hline $\begin{array}{l}13 \\
14\end{array}$ & $\begin{array}{l}8 \text { yr. } 8 \text { mth. } \\
\text { I I yr. } \\
\text { I mth. }\end{array}$ & $\begin{array}{l}\mathrm{F} \\
\mathrm{F}\end{array}$ & $\begin{array}{l}\text { No } \\
\text { No } \\
\text { Yes }\end{array}$ & $\begin{array}{l}\text { No } \\
\text { No } \\
\text { No }\end{array}$ & $\begin{array}{l}\mathbf{P}_{2} \mathbf{N t} \\
\mathrm{P}_{2} \mathrm{~N} \\
\mathrm{P}_{2} \mathrm{~N}\end{array}$ & $\begin{array}{l}\text { Same } \\
\text { Pansystolic (III/VI) } \\
\text { Pansystolic (IV/VI); } \\
\text { mid-diastolic } \\
\text { (II/VI) }\end{array}$ & $\begin{array}{l}+90 \\
+70 \\
+60\end{array}$ & $\begin{array}{l}\text { Normal ", } \\
\text { Lt. ventric. } \\
\text { hypertrophy }\end{array}$ & $\begin{array}{l}55 \\
35 \\
63\end{array}$ & $\begin{array}{l}++ \\
\mathbf{N} \\
++\end{array}$ \\
\hline
\end{tabular}

$\star$ CTR-cardiothoracic ratio.

$+\mathrm{N}$-normal.

under conservative management. At the age of 3 the child is acyanotic at rest but slightly dusky on crying.

Physical examination In group $A$ the physical examination in all cases at the initial visit showed signs of a moderately large ventricular septal defect. The pulmonary component of the second sound was consistently increased in intensity. As these patients developed infundibular stenosis the mid-diastolic flow murmur disappeared and the pansystolic murmur was replaced by a highpitched ejection systolic murmur. The pulmonary component of the second sound was then diminished, and in 2 cases it was ultimately not detectable. In group B, Cases I I and 12 had classical signs of a large ventricular septal defect while Cases 13 and 14 had physical features of a small to moderate ventricular septal defect.

Electrocardiogram The electrocardiogram in group A showed a frontal plane QRS axis varying between $\pm 0^{\circ}$ and $-100^{\circ}$. This mean axis of QRS did not vary as the patients developed infundibular stenosis. With the exception of two cases in group $\mathbf{A}$ all patients showed biventricular hypertrophy initially and continued to show this pattern during the subsequent follow-up period. Case 5 in group A showed right ventricular hypertrophy at the age of 16 months. At the age of $7 \frac{1}{2}$ years the electrocardiographic pattern still showed conspicuous right ventricular hypertrophy with strain, while Case 8 in group $A$ at the age of 5 months showed left ventricular hypertrophy.
The latter pattern persisted at the age of $4 \frac{1}{2}$ years.

In group B, Case II showed right ventricular hypertrophy throughout his clinical course. Case 12 had biventricular hypertrophy at the initial visit and this pattern did not change until after heart operation. Case 13 had a normal electrocardiogram, while Case 14 presented with left ventricular hypertrophy.

Chest $x$-ray The common denominator of the two groups in the chest $x$-ray is the rightsided aortic arch. The position of the descending aorta was variable in both groups. In 4 patients in group $\mathbf{A}$ the aorta descended on the right side of the vertebral column while in the rest of the patients the aorta crossed over to the left side in the thoracic cavity and descended on the left side of the vertebral column. In group B only one patient had a right descending aorta, and in all the others the aorta crossed over to the left and descended on the left side.

Chest $x$-rays in group A invariably showed a high cardiothoracic ratio and much increased vascularity at the initial visit. Subsequently the heart became smaller, but the most significant change lay in a conspicuous reduction of pulmonary vascularity. In group $B$ all the cases except Case 13 showed cardiomegaly and increased vascularity. Case 13 had a normal chest $x$-ray.

Haemodynamic data In group A, Cases $I$ and 2 underwent cardiac catheterization during infancy, and both were found to have significant right ventricular hypertension with no pressure difference across the outflow tract 
TABLE 3 Haemodynamic data of patients who developed progressive infundibular stenosis (group $A$ )

\begin{tabular}{|c|c|c|c|c|c|c|c|c|c|c|}
\hline \multirow{2}{*}{$\begin{array}{l}\text { Case } \\
\text { No. }\end{array}$} & \multirow[t]{2}{*}{ Age } & \multicolumn{6}{|c|}{ Pressures $(\mathrm{mm} . \mathrm{Hg})$} & \multirow{2}{*}{$\begin{array}{l}\text { Flow } \\
Q P / Q S\end{array}$} & \multirow{2}{*}{ Angiocardiography } & \multirow[t]{2}{*}{ Remarks } \\
\hline & & $R A$ & Body $^{R V}$ & Infund. & $P A$ & $S A$ & $P P / P S$ & & & \\
\hline \multirow[t]{2}{*}{$\mathbf{I}$} & 7 mth. & 2 & $105 / 0-10$ & $105 / 0$ & $90 / 34$ & $105 / 52$ & 0.86 & $3: 1$ & $\begin{array}{l}\text { Type II VSD; prominent } \\
\text { crista supraventricularis }\end{array}$ & Remains asymntomatic \\
\hline & 3 yr. $6 \mathrm{mth}$. & 3 & $90 / 0-3$ & $45 / 0$ & $45 / 18$ & $90 / 55$ & 0.50 & $2 \cdot 2: I$ & $\begin{array}{l}\text { Low infundibular steno- } \\
\text { sis with infundibular } \\
\text { chamber }\end{array}$ & Kemains asymptomatic \\
\hline \multirow[t]{2}{*}{2} & $15 \mathrm{mth}$. & 一 & $64 / 0-7$ & $64 / 0$ & $55 / 21$ & $100 / 65$ & 0.55 & $2 \cdot 2: 1$ & $\begin{array}{l}\text { Type II ventricular } \\
\text { septal defect }\end{array}$ & Continues to be \\
\hline & $4 \mathrm{yr}$. & 0 & $87 / 0$ & $53 / 0$ & $48 / 5$ & $90 / 50$ & 0.53 & $I \cdot 7: 1$ & $\begin{array}{l}\text { Anomalous muscle bundle } \\
\text { in right ventricle shown } \\
\text { as persistent filling } \\
\text { defect in RV cine- } \\
\text { angiocardiogram }\end{array}$ & asymptomatic \\
\hline 3 & $2 \frac{1}{2}$ mth. & 0 & $75 / 0-3$ & $65 / 0$ & $54 / 8$ & $88 / 43$ & 0.61 & $2 \cdot 2: 1$ & $\begin{array}{l}\text { Pulmonary valve nor- } \\
\text { mal; RV outflow slight- } \\
\text { ly narrowed and crista } \\
\text { supraventricularis } \\
\text { prominent }\end{array}$ & $\begin{array}{l}\text { At age of } 3 \mathrm{yr} \text {. } 3 \mathrm{mth} \text {. } \\
\text { patient had classical } \\
\text { signs of infundibular } \\
\text { stenosis }\end{array}$ \\
\hline 4 & 2 wk. & 5 & $69 / 0-9$ & $69 / 0$ & $67 / 10$ & $90 / 40$ & 0.75 & $2 \cdot 2: 1$ & $\begin{array}{l}\text { Type II VSD of moder- } \\
\text { ate size; hyperactive } \\
\text { infundibulum with } \\
\text { prominent crista supra- } \\
\text { ventricularis }\end{array}$ & Same as above \\
\hline 5 & $7 \mathrm{yr} .6 \mathrm{mth}$ & 2 & $110 / 0-5$ & $64 / 0$ & $24 / 6$ & $\begin{array}{l}(\mathrm{LV}) \\
\text { I0I/0-10 }\end{array}$ & $0 \cdot 24$ & $\mathbf{I} \cdot \mathbf{2}: \mathbf{I}$ & $\begin{array}{l}\text { RV heavily trabeculated } \\
\text { with conspicuous } \\
\text { narrowing of outflow } \\
\text { tract during systole }\end{array}$ & $\begin{array}{l}\text { Congestive heart failure } \\
\text { in infancy; no car- } \\
\text { diac catheterization } \\
\text { at that time; cathe- } \\
\text { terization at } 7 \text { yr. } \\
6 \text { mth. shows fea- } \\
\text { tures of } T / F\end{array}$ \\
\hline 6 & $5 \mathrm{yr}$. & 2 & $78 / 0-4$ & $54 / 0$ & $38 / 6$ & $76 / 42$ & 0.50 & $I \cdot 8: I$ & $\begin{array}{l}\text { Type II VSD; anomal- } \\
\text { ous muscle bundle } \\
\text { across RV outflow } \\
\text { tract }\end{array}$ & $\begin{array}{l}\text { Presented in infancy } \\
\text { with cardiomegaly } \\
\text { and congestive heart } \\
\text { failure }\end{array}$ \\
\hline 7 & $\begin{array}{l}5 \mathrm{yr} . \\
8 \mathrm{yr} .6 \mathrm{mth} .\end{array}$ & $\begin{array}{l}5 \\
2\end{array}$ & $\begin{array}{l}119 / 0-10 \\
94 / 0-3\end{array}$ & $\begin{array}{l}87 / 0 \\
66 / 0\end{array}$ & $\begin{array}{l}25 / 10 \\
24 / 6\end{array}$ & $\begin{array}{r}122 / 57 \\
96 / 62\end{array}$ & $\begin{array}{l}0.20 \\
0.25\end{array}$ & $\begin{array}{l}1 \cdot 4: I \\
I \cdot 2: I\end{array}$ & $\begin{array}{l}\text { Type III VSD; heavily } \\
\text { trabeculated RV with } \\
\text { narrowing of infundi- } \\
\text { bulum during systole } \\
\text { with thickened pul- } \\
\text { monary valve }\end{array}$ & $\begin{array}{l}\text { Total correction at } 9 \\
\text { yr.; at operation, } \\
\text { moderate valvular } \\
\text { and infundibular } \\
\text { stenosis noted }\end{array}$ \\
\hline 8 & 4 yr. 6 mth. & 2 & $62 / 0-7$ & $54 / 0$ & $30 / 18$ & $122 / 8 I$ & 0.25 & $I \cdot 7: I$ & $\begin{array}{l}\text { Moderate size Type II } \\
\text { VSD; no RV cine- } \\
\text { angiocardiogram }\end{array}$ & $\begin{array}{l}\text { Total correction at } \\
6 \text { yr.; VSD closed } \\
\text { with Teflon patch } \\
\text { and pulmonary valve } \\
\text { stenosis relieved by } \\
\text { commissurotomy }\end{array}$ \\
\hline 9 & $13 \frac{1}{2}$ mth. & N.K. & $88 / 0$ & N.K. & N.K. & $93 / 57$ & N.K. & $I \cdot 8: I$ & $\begin{array}{l}\text { Large VSD with infundi- } \\
\text { bular stenosis }\end{array}$ & $\begin{array}{l}\text { Total correction at } \\
4 \text { yr. } 6 \text { mth.; at } \\
\text { operation large VSD } \\
\text { and infundibular } \\
\text { stenosis noted }\end{array}$ \\
\hline Io & $8 \mathrm{yr}$. & 0 & $92 / 0-7$ & $32 / 0$ & $23 / 7$ & $93 / 63$ & 0.25 & $I \cdot 8: I$ & $\begin{array}{l}\text { Type II VSD; heavily } \\
\text { trabeculated RV with } \\
\text { infundibular stenosis }\end{array}$ & $\begin{array}{l}\text { Total correction at } \\
9 \text { yr.; at operation, } \\
\text { VSD closed with } \\
\text { Teflon patch and } \\
\text { infundibular stenosis } \\
\text { resected }\end{array}$ \\
\hline
\end{tabular}

*Type II VSD-involving the membranous septum, Type III VSD-located under posterior leaflet of tricuspid valve close to annulus. N.K. = Not Known; T/F = Tetralogy of Fallot. 
TABLE 4 Haemodynamic data of patients who did not develop progressive infundibular stenosis (group B)

\begin{tabular}{|c|c|c|c|c|c|c|c|c|c|c|}
\hline \multirow{2}{*}{$\begin{array}{l}\text { Case } \\
\text { No. }\end{array}$} & \multirow[t]{2}{*}{ Age } & \multicolumn{6}{|c|}{ Pressures $(\mathrm{mm} . \mathrm{Hg})$} & \multirow{2}{*}{$\begin{array}{l}\text { Flow } \\
Q P / Q S\end{array}$} & \multirow[t]{2}{*}{ Angiocardiography ${ }^{\star}$} & \multirow[t]{2}{*}{ Remarks } \\
\hline & & $R A$ & Body $^{R V}$ & Infund. & $P A$ & $S A$ & $P P / P S$ & & & \\
\hline II & $\begin{array}{l}3 \frac{1}{2} \text { mth. } \\
9 \frac{1}{2} \text { mth. }\end{array}$ & $\begin{array}{l}0 \\
0\end{array}$ & $\begin{array}{l}66 / 0-5 \\
69 / 0-4\end{array}$ & $\begin{array}{l}62 / 0 \\
69 / 0\end{array}$ & $\begin{array}{l}66 / 13 \\
52 / 10\end{array}$ & $\begin{array}{l}78 / 45 \\
89 / 51\end{array}$ & $\begin{array}{l}0.85 \\
0.59\end{array}$ & $\begin{array}{l}1 \cdot 6: 1 \\
1 \cdot 5: 1\end{array}$ & $\begin{array}{l}\text { Large Type II VSD; no } \\
\text { infundibular stenosis }\end{array}$ & $\begin{array}{l}\text { At } 9 \frac{1}{2} \text { mth. main pul- } \\
\text { monary artery ban- } \\
\text { ded because of per- } \\
\text { sistent heart failure }\end{array}$ \\
\hline 12 & 8 yr. $8 \mathrm{mth}$. & 3 & $70 / 0-5$ & $60 / 0$ & $59 / 18$ & $105 / 61$ & 0.56 & $3: 1$ & $\begin{array}{l}\text { Large Type II VSD; no } \\
\text { infundibular stenosis }\end{array}$ & $\begin{array}{l}\text { At } 9 \text { yr. Type II VSD } \\
\text { closed using Teflon } \\
\text { patch }\end{array}$ \\
\hline 13 & II yr. & 0 & 19/0-I & $19 / 0$ & $18 / 8$ & $104 / 69$ & 0.17 & I:I & $\begin{array}{l}\text { Small VSD with aneu- } \\
\text { rysms of membranous } \\
\text { septum }\end{array}$ & $\begin{array}{l}\text { Shunt detected by } \\
\text { angio and hydrogen } \\
\text { curves }\end{array}$ \\
\hline 14 & I mth. & 0 & $45 / 0-5$ & $45 / 0$ & $33 / 13$ & $70 / 31$ & 0.47 & $2 \cdot 4: 1$ & $\begin{array}{l}\text { Moderate size VSD; no } \\
\text { infundibular stenosis }\end{array}$ & $\begin{array}{l}\text { Clinically, VSD getting } \\
\text { smaller }\end{array}$ \\
\hline
\end{tabular}

$\star$ See footnote Table 3 .

of the right ventricle. They had moderately severe left-to-right shunts at ventricular level. Both were recatheterized, at the age of $3 \frac{1}{2}$ years and 4 years, respectively. By that time the right ventricular hypertension had reached systemic level, significant infundibular stenosis had developed, and the left-to-right shunt had become smaller (Table 3 ).

In Cases 3 and 4 of group A, the catheterization performed in infancy showed moderate size ventricular septal defects, a pulmonary to systemic flow ratio of $2 \cdot 2: I$, and systolic pulmonary artery pressures 65 to 75 per cent of systemic pressure, with no pressure difference across the outflow tract. These 2 patients in three years had developed physical signs of infundibular stenosis, and Case 4 even had a few cyanotic episodes at the age of 2 years.

All other cases in group A except Case ro presented in infancy with congestive heart failure. These patients were catheterized at the age of $4 \frac{1}{2}$ years or above, and the haemodynamic data were almost identical. They all had normal pulmonary artery pressure, significant infundibular stenosis, and systemic systolic pressure level in the right ventricle. The ratio of pulmonary to systemic flow was less than 2: I. In Case 7 cardiac catheterization was repeated at the age of 9 , four and a half years after the initial cardiac catheterization. The data were exactly the same.

In group B Case II had cardiac catheterization repeated after a six-month interval. At the second study there was $17 \mathrm{~mm}$. $\mathrm{Hg}$ pressure difference across the pulmonary valve, though at the cine-angiocardiogram the pulmonary valve and infundibulum appeared normal. This pressure difference was attributed to the flow. Case 12 presented in conges- tive heart failure in infancy and was catheterized at the age of 9 years. The study showed a ventricular septal defect with pulmonary to systemic blood flow ratio of $3: 1$, a systolic pulmonary artery pressure 60 per cent of systemic, and a minimal pressure difference across the infundibulum. Case 13 had a small ventricular septal defect and normal pressures in the right side. Case 14 at $\mathrm{I}$ month of age showed a moderate-sized ventricular septal defect, with the pressure in the right ventricle and pulmonary artery half the systemic level.

Angiocardiography Right ventricle angiocardiograms in 3 infants from group A showed a prominent crista supraventricularis, hyperdynamic infundibulum, and a normal pulmonary valve ring. In only one patient was the pulmonary valve ring small. These features were present even in the absence of any pressure difference across the outflow tract. In older children from group $A$ the angiocardiograms showed conspicuous infundibular narrowing with an infundibular chamber. The prominent crista supraventricularis was encroaching into the right ventricular outflow tract. In addition, 2 patients had an anomalous muscle bundle across the outflow tract, seen on the angiocardiogram as a persistent filling defect. In group $B, 2$ patients with a large ventricular septal defect showed a normal outflow tract and dilated pulmonary artery. Case I3 in this group showed an aneurysm of the membranous septum, while in Case 14 a moderate size ventricular septal defect with normal outflow tract was visualized.

Operation Four patients from group A underwent open-heart operation. In 2 patients 
the anatomy of the right ventricular outflow tract was that of tetralogy of Fallot, there being hypertrophy of the parietal and moderator bands. The ventricular septal defect was Type II (Cooley, Garrett, and Howard, I962). The annulus of the pulmonary valve was normal as compared to the narrow annulus seen in the classical tetralogy of Fallot. In one patient there was associated pulmonary valve stenosis and in another (Case 8) the dominant area of stenosis was at pulmonary valve level.

\section{Discussion}

Rowe, Vlad, and Keith (1955) reported 4 cases of atypical tetralogy of Fallot characterized by the absence of cyanosis and increased vascularity in the chest $x$-ray. Cardiac catheterization showed normal or subnormal pressures in the pulmonary artery, systemic pressure in the right ventricle, and normal $\mathrm{O}_{2}$ saturation in the systemic artery. One of their cases had a right aortic arch. The authors added 2 additional cases as an addendum to the paper, both of which also had an associated right aortic arch.

Gasul et al. (1957) presented for the first time the evidence for acquired infundibular stenosis in uncomplicated ventricular septal defect by serial cardiac catheterization in 3 infants, one whom had a right aortic arch. Lynfield et al. (I96I), reporting on the natural history of ventricular septal defect, added 2 more cases of acquired infundibular stenosis with ventricular septal defect to the original Gasul series but did not mention any association with right aortic arch.

Fyler et al. (1958) recorded 5 cases of right aortic arch in 103 patients with ventricular septal defect. Four cases had pulmonary stenosis of varying degree, and one patient had a small ventricular septal defect.

In the present series there are 14 cases of ventricular septal defect with right aortic arch: Io developed progressive infundibular stenosis (group A) and 4 of them did not (group B). In the latter group, one required pulmonary artery banding at the age of 9 months, another had closure of his ventricular septal defect at the age of $8 \frac{1}{2}$ years, and the other 2 had small to moderate size ventricular septal defects.

The presenting features in the two groups are indistinguishable. In group A, all except one presented in congestive heart failure, and in group B, 3 out of 4 had congestive heart failure. All patients in group A responded to medical management. The physical signs at the initial visit were those of a large ventricular septal defect and pulmonary hypertension, but as the patients developed infundibular stenosis, the murmur changed its character to that of a high-pitched ejection murmur, and the pulmonary component of the second heart sound diminished. Often the middiastolic flow murmur disappeared (Table I). Definite auscultatory features of obstruction occurred only when the patient had established infundibular stenosis. During the transitional phase the auscultatory findings can be confusing, and it is often impossible at times to differentiate the two types of systolic murmurs (Wood, Magidson, and Wilson, 1954; Nadas, 1963).

Initially, chest $x$-rays of patients in group A showed cardiomegaly and increased vascularity. As they developed progressive infundibular stenosis, the heart became smaller and the vascularity diminished.

The electrocardiogram in the original Gasul series showed biventricular hypertrophy (Gasul et al., 1957). In the present series, the electrocardiogram in group A was not influenced by the development of infundibular stenosis. Except for 2 patients, the electrocardiogram showed biventricular hypertrophy initially, and continued to show biventricular hypertrophy in spite of the development of significant infundibular obstruction. It appears that the electrocardiogram lags behind the haemodynamic alteration in this clinical situation.

In group A, cardiac catheterization in infancy showed significant right ventricular hypertension, with either no difference or very minimal pressure difference across the outflow tract. As patients developed infundibular stenosis, the pulmonary artery pressure became normal and the right ventricular pressure in most of the cases reached systemic level. Cine-angiocardiography, in the early stage, showed a prominent crista, and even though there was no haemodynamically significant obstruction, the outflow tract appeared narrow and hyperdynamic (Fig.). The annulus of the pulmonary valve, though smaller than that seen in an uncomplicated ventricular septal defect, appeared relatively normal on the angiocardiogram and also at operation when compared with classical tetralogy of Fallot. Once these patients developed obstruction, an infundibular chamber with or without a muscle band was seen.

The course of the patients in group A seems to be uniform. Both in the Gasul series and in the present series the patients presented in infancy in congestive heart failure. Gasul et al. (1957) and Lynfield et al. (I96I) reported that their patients developed significant obstruction before the age of 4 , and those of our patients in whom we could document 
the development of obstruction all seemed to have developed it before the age of 4. Bloomfield (1964) reported one patient in his study of the natural history of ventricular septal defect, who developed significant right ventricular infundibular obstruction in the fifth decade. We have also seen one patient with left aortic arch and ventricular septal defect who developed significant infundibular obstruction between the ages of 9 and 12 (J. R. Allen, P. J. Varghese, and R. D. Rowe, unpublished data).

Right aortic arch in uncomplicated ventricular septal defect is a rare occurrence (Nadas, 1963). Keith (1956) reported I example in 400 patients with ventricular septal defect. On the other hand, Becu et al. (1956) gave a figure of 6 per cent for 50 patients with ventricular septal defect proved at necropsy, and Edwards et al. (1965) gave a 5 per cent frequency figure for right aortic arch in uncomplicated ventricular septal defect. Discrepancy in the reported frequency of right aortic arch in ventricular septal defect may be the result of the different age-group of patients studied by each author: the frequency of right aortic arch will be high if one is looking only at ventricular septal defect in infancy. During infancy a significant number of ventricular septal defects would have closed spontaneously (Bloomfield, I964; Hoffman and Rudolph, 1965), and most of the transformations of ventricular septal defect into ventricular septal defect and pulmonary stenosis would have occurred before the age of 4 (Gasul et al., 1957; Lynfield et al., 1961). As shown by the present series, a high percentage of the latter group will have right-sided aortic arch. Because of all these factors we chose to study roo consecutive patients whose age was 5 years or above at the time of cardiac catheterization, and who were shown at catheterization to have an isolated ventricular septal defect. Out of these 100 patients, only 2 had right-sided aortic arch.

Right-sided aortic arch may have a right or a left descending aorta. Right aortic arch with a left descending aorta is often associated with an otherwise normal heart (Blackford, Davenport, and Bayley, 1932; Arkin, 1936). The crossover to the left side occurs behind the oesophagus and may occur at any level in the thoracic cavity. In the present series, $4 \mathrm{pa}$ tients in group A and one patient in group B had right descending aorta and all the other patients had a left descending aorta. Thus, the position of the descending aorta does not seem to influence the type of cardiac lesion nor does it influence the natural history of the lesion.
The observation that the majority of patients with ventricular septal defect and right aorta develop progressive infundibular stenosis is an important one, but does not answer the obvious question why some infants with ventricular septal defect and pulmonary hypertension develop progressive infundibular stenosis, especially if they have right aortic arch. Lynfield et al. (I96I) postulated that progressive infundibular stenosis might be the result of an abnormally placed crista supraventricularis and a distorted right ventricular outflow tract. He also felt that the deformity of the right ventricular outflow tract might be due to the hypertrophy of parietal and septal bands.

On the other hand, Grant, Downey, and MacMahon (196I), after a detailed dissection of the right ventricular outflow tract of normal and congenitally abnormal human hearts, postulated that the outflow tract anomalies, such as septal defects and infundibular stenosis, are the direct consequences of a primordial injury. According to these authors, injury may cause failure of one cardiac anlage to develop or hypertrophy of another. The former might result in septal defect and the latter may progress into infundibular stenosis, with the severity and timing of the injury determining whether it would fail to develop or undergo hypertrophy.

Watson and Lowe (1965) reported their study on functional adaptation of the right ventricular outflow, and related this to the development of the acquired pulmonary stenosis. They postulated that the acquired pulmonary stenosis was the result not only of the structural abnormality of the outflow but also the physical forces applied to that area. The present series supports this hypothesis. The group A patients showed structural abnormality in the cine-angiocardiogram in the absence of obstruction. In our experience, the right ventricular cine-angiocardiogram in these infants, even in the absence of any obstruction, did show an abnormal crista supraventricularis and a narrow, hyperdynamic outflow tract (Fig.). These patients also had a large left-to right shunt at the initial cardiac catheterization. It is possible that progressive obstruction in the infundibular area may be the end result of a large flow through an abnormal outflow tract.

An alternative explanation for progressive infundibular stenosis is the abnormal contraction of muscle bundles of the outflow tract, as has been postulated for obstructive cardiomyopathy (Harrison et al., 1963). Johnson (I96I) proposed this as an aetiological factor for cyanotic spells in some cases of 


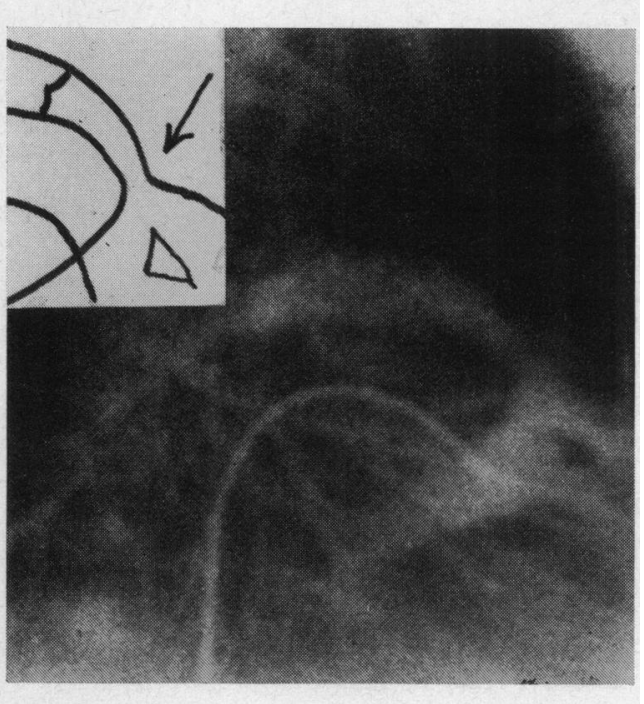

FIG. Right ventricular cine-angiocardiograms in right anterior oblique position in a patient from group $A$ at the age of 2 weeks. Note the much narrowed right ventricular outflow tract, normal annulus, and normal size pulmonary artery. At this cardiac catheterization there was no demonstrable pressure difference across the outflow tract, but at the age of 2 years this patient developed significant infundibular obstruction and cyanotic spells.

tetralogy of Fallot, and suggested that this abnormal muscular contraction was a response to sympathetic stimuli. Later clinical trials with beta-blocking agents showed conspicuous improvements in selected patients with cyanotic spells (Honey, Chamberlain, and Howard, 1964; Singh and Gotsman, 1966). It is not uncommon for patients with ventricular septal defect and pulmonary stenosis to develop cyanotic attacks, as was seen in Case 4 of the present series. Since the infundibular stenosis is an acquired one, these patients should respond well to the beta-blocking agents. In a recent report on successful long-term treatment of tetralogy of Fallot with propranolol, 6 out of the Io reported cases had right aortic arch (Eriksson, Thorén, and Zetterqvist, 1969). This raises the question whether these patients might have had a ventricular septal defect as the sole lesion which later developed progressive infundibular stenosis.

In addition to the diffuse muscular hypertrophy and obstruction of the right ventricular outflow tract, discrete anomalous muscle bundles can also cause severe obstruction of the outflow tract of the right ventricle (Lucas et al., 1962). Recently, Hartmann, Goldring, and Carlsson (1964) reported 3 patients with anomalous muscle bundle and ventricular septal defect in whom cardiac catheterization in infancy showed large left-to-right shunt with no obstruction but the angiocardiogram showed the anomalous muscle bundle. Repeat cardiac catheterization at a later age showed significant obstruction in the outflow tract. On this evidence, Hartmann et al. (1964) postulated that hypertrophy of the anomalous muscle bundle and obstruction might have occurred as a result of the large flow. In the present series in group A, two patients had discrete anomalous muscle bundle and both of them developed progressive infundibular stenosis.

Does the persistence of a right arch of the aorta rather than the left predispose the foetus to the development of ventricular septal defect, and if so, do the defects that result differ in terms of size, shape, and location from those seen in other syndromes? Rychter (I962) has noted in the chick embryo (which normally has a right-sided aortic arch) that when the right fourth arch is ligated, the right third arch becomes the preferred vessel. If both right third and fourth arches are disturbed, either the left third or fourth arch becomes the dominant vessel, and persists along with a 38 per cent chance of a coexisting ventricular septal defect. Though the size, shape, and position of the ventricular septal defect which appears as a secondary anomaly in these cases has not been described, in other experiments involving suppression of various arches, the ventricular septal defects which result may be triangular, infundibular, semilunar, or tear-drop shaped, and located in either an anterior or posterior position in the septum between the ventricles, depending upon the haemodynamics of the disturbed circulation. Since the intracardiac anomalies in Rychter's experiments were the result of altering the circulation in the aortic arches, it it tempting to conclude that in the human also, a ventricular septal defect and perhaps altered architecture of the infundibulum may in some cases follow the development of a right-sided arch. However, the opposite may also be true, that right aortic arch will result in cases of ventricular septal defect, and/or altered cushions or developing muscle bundles if the blood flow from the left side of the heart is directed into the right instead of the left arch. In either case, the association of right aortic arch with ventricular septal defect and an abnormal arrangement of the muscles in the right ventricular outflow tract need not be associated with hypertrophy of the infundibulum until the outflow tract is stimulated to hypertrophy later in development. Such a 
stimulus may be haemodynamic, electrophysiological, or humoral.

Apart from the interest in the mechanism of transformation of ventricular septal defect into that of ventricular septal defect with progressive infundibular stenosis, this group of patients raises some important practical points regarding management and prognosis of ventricular septal defect in infancy. Infants with a ventricular septal defect and rightsided aortic arch seem to follow a different course from an ordinary ventricular septal defect. The present series indicates that even though these infants present in congestive heart failure they should be managed conservatively because Io out of the I4 patients in this series developed progressive infundibular stenosis in two or three years and only one patient needed pulmonary artery banding. Moreover, if these patients develop cyanotic spells as a result of severe infundibular stenosis, it appears they would be ideal candidates for treatment with beta-blocking agents.

Infants with ventricular septal defect and right-sided aortic arch who develop progressive infundibular stenosis can be differentiated from the patients with ordinary ventricular septal defect by right ventricular angiocardiograms. In the former group the right ventricular angiocardiogram invariably showed a prominent crista supraventricularis, a narrow hyperdynamic outflow tract of the right ventricle, and a normal annulus even in the absence of any obstruction, whereas the latter group showed a normal outflow tract, dilated annulus, and a prominent main pulmonary artery. This angiocardiographic sign seems to differentiate the course of these two groups and appears to be a helpful sign in predicting the prognosis of an infant with ventricular septal defect and right-sided aortic arch who presents in congestive heart failure.

\section{References}

Arcilla, R. A., Agustsson, M. H., Bicoff, J. P., Lynfield, J., Weinberg, M., Fell, E. H., and Gasul, B. M. (1963). Further observations on the natural history of isolated ventricular septal defects in infancy and childhood. Serial cardiac catheterization studies in 75 patients. Circulation, 28, 560.

Arkin, A. (1936). Double aortic arch with total persistence of the right and isthmus stenosis of the left arch: a new clinical and x-ray picture. Report of six cases in adults. American Heart fournal, II, 444.

Becu, L. M., Fontana, R. S., DuShane, J. W., Kirklin, J. W., Burchell, H. B., and Edwards, J. E. (1956). Anatomic and pathologic studies in ventricular septal defect. Circulation, 14, 349.

Blackford, L. M., Davenport, T. F., and Bayley, R. H. (1932). Right aortic arch. I. Clinical report of a case with associated anomalies. American fournal of Diseases of Children, 44, 823.
Bloomfield, D. K. (1964). The natural history of ventricular septal defect in patients surviving infancy. Circulation, 29, 914.

Cooley, D. A., Garrett, H. E., and Howard, H. S. (I962). The surgical treatment of ventricular septal defect. An analysis of 300 consecutive surgical cases. Progress in Cardiovascular Disease, 4, 312.

Edwards, J. E., Carey, L. S., Neufeld, H. N., and Lester, R. G. (1965). Congenital Heart Disease, Vol. I, p. I40. W. B. Saunders, Philadelphia.

Eriksson, O. B., Thorén, C., and Zetterqvist, P. (1969). Long-term treatment with propranolol in selected cases of Fallot's tetralogy. British Heart fournal, 31, 37.

Fyler, D. C., Rudolph, A. M., Wittenborg, M. H., and Nadas, A. S. (1958). Ventricular septal defect in infants and children. A correlation of clinical, physiologic, and autopsy data. Circulation, 18, 833.

Gasul, B. M., Dillon, R. F., Vrla, V., and Hait, G. (1957). Ventricular septal defects. Their natural transformation into those with infundibular stenosis or into the cyanotic or noncyanotic type of tetralogy of Fallot. Fournal of the American Medical Association, 164, 847.

Grant, R. P., Downey, F. M., and MacMahon, H. (I96I). The architecture of the right ventricular outflow tract in the normal human heart and in the presence of ventricular septal defects. Circulation, $24,223$.

Harrison, D. C., Ross, J., Glick, G., Chidsey, C. A., and Braunwald, E. (1963). Hemodynamic effects of beta-adrenergic blockade in hypertrophic subaortic stenosis. Clinical Research, II, 167.

Hartmann, A. F., Jr., Goldring, D., and Carlsson, E. (I964). Development of right ventricular obstruction by aberrant muscular bands. Circulation, 30, 679.

Hoffman, J. I. E., and Rudolph, A. M. (1965). The natural history of ventricular septal defects in infancy. | American fournal of , Cardiology, 16, 634.

Honey, M., Chamberlain, D. A., and Howard, J. (1964). The effect of beta-sympathetic blockade on arterial oxygen saturation in Fallot's tetralogy. Circulation, 30, 501.

Johnson, A. M. (196r). Norepinephrine and cyanotic attacks in Fallot's tetralogy. British Heart fournal, 23, 197.

Keith, J. D. (1956). The diagnosis of ventricular septal defect. In Second World Congress Cardiology, Washington, D.C., r954.

Kidd, L., Rose, V., Collins, G., and Keith, J. (1965). The hemodynamics in ventricular septal defect in childhood. American Heart fournal, 70, 732.

Lucas, R. V., Jr., Varco, R. L., Lillehei, C. W., Adams, P., Jr., Anderson, R. C., and Edwards, J. E. (1962). Anomalous muscle bundle of the right ventricle. Hemodynamic consequences and surgical considerations. Circulation, 25, 443.

Lynfield, J., Gasul, B. M., Arcilla, R., and Luan, L. L. (196I). The natural history of ventricular septal defects in infancy and childhood, based on serial cardiac catheterization studies. American fournal of Medicine, 30, 357.

Nadas, A. S. (1963). Pediatric Cardiology, 2nd ed., pp. 415 and 429. W. B. Saunders, Philadelphia.

Ritter, D. G., Feldt, R. H., Weidman, W. H., and DuShane, J. W. (1965). Ventricular septal defect. Circulation, 32, Suppl. 3, 42.

Rowe, R. D., Vlad, P., and Keith, J. D. (1955). Atypical tetralogy of Fallot: a noncyanotic form with increased lung vascularity. Circulation, 12, 230. 
Rychter, Z. (1962). Experimental morphology of the aortic arches and the heart loop in chick embryos. Advances in Morphogenesis, 2, 333.

Singh, S. P., and Gotsman, M. S. (1966). Pronethalol for cyanotic attacks. British Heart fournal, 28, 98.

Watson, H., and Lowe, K. G. (1965). Functional adaptations of the right ventricular outflow tract in congenital heart disease. British Heart fournal, 27, 408.

Wood, P., Magidson, O., and Wilson, P. A. O. (1954). Ventricular septal defect with a note on acyanotic Fallot's tetralogy. British Heart fournal, 16, 387. 